\title{
Giardiasis in daycare centers at Rancabali tea plantation, Bandung District, Indonesia
}

\author{
Endang Widajanti, MD; Herry Garna, MD, PhD; Alex Chairulfatah, MD; Dadang Hudaya, MD
}

\begin{abstract}
Background In developing countries, the prevalence of giardiasis in daycare centers is considerably high. There had been inadequate report of giardiasis in Indonesia.

Objective To know the prevalence of giardiasis in children and the number of children with symptomatic and asymptomatic giardiasis who attended daycare centers at Rancabali tea plantation, Bandung district.

Methods This descriptive study was conducted in daycare centers between August to October 2002. Giardiasis was defined as the occurrence of $G$. lamblia cyst in stool specimen independent from the presence or absence of symptoms. Four of 12 daycare centers were chosen by cluster random sampling. All children aged 1 to 60 months attending daycare and staying for at least 2 weeks were included in this study. Three consecutive stool specimen preserved by $10 \%$ formalin, concentrated by formalin ether, were examined microscopically to find the G. lamblia cyst.

Results Giardia lamblia cysts were found in 27 (29\%) of the 92 children attending the daycare centers at Rancabali tea plantation $(95 \% \mathrm{Cl} 20 ; 38.6 \%)$. Of these children, 15 showed symptoms such as diarrhea episodes ( 8 children), diarrhea ( 5 children), bloating ( 5 children), abdominal cramp ( 5 children), and vomiting ( 3 children). Three children showed mild to moderate malnutrition. Ten children aged 13 to 36 month-old with G. lamblia-positive stool showed such symptoms.

Conclusion The prevalence of G. lamblia infection in children attending daycare centers at Rancabali tea plantation was almost similar with other place in developing countries. More than half of patients had symptomatic disease [Paediatr Indones 2003;43:158-161].
\end{abstract}

Keywords: Giardia lamblia, daycare center, stool specimen, tea plantation

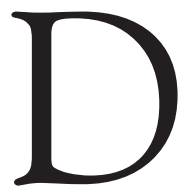
aycare centers constitute a reservoir for a large number of infectious diseases. Several factors account for this, including overcrowding of young children unaware of personal hygiene principles, frequent child to child contact, lack of fecal continence before toilet training, repeated mouth contact with hands and objects, and needs for frequent hands-on child contact by staff. ${ }^{1-4}$ Illness in these children has an impact not only on the health of the child but also on the parents' ability to work, the health of other children, and family members. ${ }^{2}$ Giardia lamblia is one of the enteric pathogens that has been associated with outbreaks of diarrhea illness in the daycare center (DCC) environment. ${ }^{5}$ Giardiasis was defined as the occurrence of G. lamblia in stool specimen independent from the presence or absence of symptoms. ${ }^{5}$ Giardiasis has a wide spectrum of clinical expression. Although most G. lamblia infections are asymptomatic or characterized by only mild signs or symptoms, prolonged diarrhea with malnutrition and growth failure in infancy has also been described. $1,4,6$ 10 The prevalence of giardiasis is $2-5 \%$ in industrialized

From the Department of Child Health, Medical School, Padjadjaran University, Hasan Sadikin Hospital, Bandung.

Reprint requests to: Endang Widajanti, MD, Department of Child Health, Medical School, Padjadjaran University, Hasan Sadikin Hospital, Bandung, Indonesia. Tel. 62-22-2011282, Fax. 62-22-2032216.

158 - Paediatrica Indonesiana, Vol. 43 No. 9-10 - September - October 2003 
countries and $20-30 \%$ in developing countries. ${ }^{6}$ The prevalence in Peruvian children reached $40 \%$ by the age of 6 months, and stool examination confirmed prevalence rates of about $20 \%$ in children in Zimbabwe and Bangladesh. In Houston, however, G. lamblia was detected in $33 \%$ of DCC children. ${ }^{5}$ Direct personto-person spread by fecal-oral transmission certainly accounts for the high prevalence of giardiasis in DCCs, where prevalence may be as high as 35\%.6,7 The examination of stool looking for trophozoites or cysts remains the test of choice in most cases and is the standard to which other assays are compared. 3,6,8,11-14

There are a lot of daycare centers at Rancabali tea plantation, so we intended to know the prevalence of giardiasis in children and the number of children with symptomatic and asymptomatic giardiasis who attended daycare centers at that area.

\section{Methods}

This descriptive study was conducted between August and October 2002. Of 12 daycare centers at Rancabali tea plantation, Bandung district, West Java Indonesia,

Table 1. Characteristic of subjects

\begin{tabular}{|c|c|c|}
\hline Characteristic & Number & $\%$ \\
\hline \multicolumn{3}{|l|}{ Sex } \\
\hline Male & 54 & 59 \\
\hline Female & 38 & 41 \\
\hline \multicolumn{3}{|l|}{ Age (month) } \\
\hline $1-12$ & 9 & 10 \\
\hline $13-36$ & 41 & 45 \\
\hline $37-60$ & 42 & 46 \\
\hline : $35.6(16.8)$ & & \\
\hline Range $\quad: 2-60$ months & & \\
\hline \multicolumn{3}{|l|}{ Nutritional status } \\
\hline Well-nourished & 75 & 82 \\
\hline Mild malnutrition & 15 & 16 \\
\hline Moderate malnutrition & 2 & 2 \\
\hline Severe malnutrition & 0 & 0 \\
\hline \multicolumn{3}{|l|}{ Daycare centers } \\
\hline Walini & 26 & 28 \\
\hline Cirengganis & 14 & 15 \\
\hline Bayongbong & 22 & 24 \\
\hline Sindang Reret & 30 & 33 \\
\hline \multicolumn{3}{|c|}{ Duration of attendance in daycare center } \\
\hline 2 weeks $-<6$ months & 12 & 13 \\
\hline$\geq 6$ months & 80 & 87 \\
\hline$X(S D) \quad: 25.0(16.6)$ & & \\
\hline : 1-60 months & & \\
\hline
\end{tabular}

4 centers were chosen by cluster random sampling. All children attending the daycare centers for at least 2 weeks, aged 1 to 60 months, and permitted by their parents, were enrolled in this study. All subjects' identity was recorded, including age, sex, and duration of attendance in the daycare centers. All data were collected by a questionnaire that was given to the parents. The questionnaire also included information of diarrhea, abdominal pain, bloating, and vomiting. The weight and height of the child were measured. Three consecutive stool samples were collected. Each stool sample was put in a pot and preserved in 10\% formalin, and then delivered to the Parasitology laboratory, Medical School, Padjadjaran University in order to find Giardia lamblia cyst. Concentration techniques were designed to concentrate the parasites into a small volume of fluid and removed as much debris as possible. The concentrate was examined, stained with iodine. The formalin-ether method was used in this study. The specimens were examined microscopically using lower-power magnification (40x objective) and high-power magnification (100x objective).

\section{Results}

There were 92 children who met the inclusion criteria. Sex distribution was nearly equal between male and female. This study showed that the number of children aged less than 1 year-old was less than they who aged more than 1 year-old. Most subjects were wellnourished (82\%), while the rest were malnourished. Most of them had been attending the daycare center for more than 6 months.

Four daycare centers participated in this study caring 92 children aged 1-60 months; 26 (28\%) subjects in Walini daycare center, $14(15 \%)$ in Cirengganis, 22 (24\%) sin Bayongbong, and 30 (33\%) in Sindang Reret daycare center. The characteristics of the subjects are presented in Table 1 .

From this study, we found G. lamblia cysts in stool specimen among 27 (29\%) subjects with 95\% confidence interval of $20.0 ; 38.6 \%$.

Of 27 children who excreted Giardia lamblia cysts, 15 children were symptomatic while 12 were asymptomatic. The clinical manifestations of giardiasis found in this study varied. Five children had diarrhea, 
8 children had diarrhea episodes, 5 children had bloating, 5 children had abdominal cramp, and 3 children had vomiting. Three children showed mild to moderate malnutrition. The study showed that among them who excreted Giardia lamblia cysts, male was more affected than female (16 male vs. 11 female). Children aged more than 1 year-old excreted Giardia lamblia cysts more often than those aged less than 1 year-old.

The nutritional status of subjects who excreted Giardia lamblia cysts were mostly well-nourished and most of them had been attending the daycare center for more than 6 months.

TABLE 2. Characteristics of GIARDIASIS WITH VARIOUS VARIABLES

\begin{tabular}{|c|c|c|}
\hline \multicolumn{2}{|c|}{ Variable } & \multirow{2}{*}{$\begin{array}{c}\text { G. lamblia -positive stool } \\
n\end{array}$} \\
\hline 1. & Clinical manifestation & \\
\hline & + & 15 \\
\hline & - & 12 \\
\hline \multicolumn{3}{|c|}{ 2. Sex } \\
\hline & Male & 16 \\
\hline & Female & 11 \\
\hline \multicolumn{3}{|c|}{ 3. Age (month) } \\
\hline & $1-12$ & 3 \\
\hline & $13-36$ & 12 \\
\hline & $37-60$ & 12 \\
\hline \multicolumn{3}{|c|}{ 4. Nutritional status } \\
\hline & Well-nourished & 19 \\
\hline & Malnutrition & 8 \\
\hline \multicolumn{3}{|c|}{$\begin{array}{l}\text { Duration of attendance in } \\
\text { daycare center }\end{array}$} \\
\hline & 2 weeks $-<6$ months & 4 \\
\hline & $\geq 6$ months & 23 \\
\hline
\end{tabular}

Among 12 subjects from age group of $13-36$ months who excreted Giardia lamblia cysts in their stool, 10 clinical manifestations of giardiasis while subjects from the other age group did not show significant clinical manifestations as the former (Table 3).

Table 3. The distribution of G. lamblia positive stool ACCORDING TO AGE GROUP

\begin{tabular}{lll}
\hline Age (month) & $\begin{array}{l}\text { Clinical } \\
\text { Manifestation }\end{array}$ & $\begin{array}{l}\text { G. lamblia- } \\
\text { positive stool } \\
\mathbf{n}\end{array}$ \\
\hline $1-12$ & + & 2 \\
$13-36$ & - & 1 \\
& + & 10 \\
$37-60$ & - & 2 \\
& + & 3 \\
\hline
\end{tabular}

\section{Discussion}

The prevalence of $29 \%$ children with Giardia-positive stool in this study was not different from the result of the study performed by Pickering et al which showed that $33 \%$ of subjects attending daycare were infected by Giardia lamblia. ${ }^{1}$ A study done in Yerusalem found that the prevalence of giardiasis in children attending daycare was $37 \%{ }^{3}$ Farthing et al and Ortega showed that the prevalence of giardiasis can be as high as 35\% among children attending child care centers. 6,7 Several factors account for this, including overcrowding of young children unaware personal hygiene principles, repeated mouth contact with hands and objects, and need for frequent hands-onchild contact by staff. 1,2,4

In this study, we found a high prevalence of symptomatic giardiasis. This result was quite different from studies performed before, which showed that G. lamblia infection was mainly asymptomatic. It is possible that in some symptomatic Giardia-positive children, illness may have been caused by other unidentified agents, unrelated to their excretion of this parasite. $2,3,9$

From this study we also found that giardiasis was independently associated with sex and nutritional state of the subject. Early studies in Guatemala suggested that in the second year of life, G. lamblia infection affects growth. However, more recent studies showed that there is no effect of G. lamblia carriage on growth. ${ }^{1,9}$

The children who attended the daycare center for at least 6 months seemed to excrete G. lamblia cysts more than those who attended the daycare of less than 6 months. A study showed that children attending a daycare center for longer periods were more likely to harbor cysts and trophozoites. Pickering et al suggested that children with daycare center exposure longer than 6 months had significantly greater frequency of cysts in their stool specimen than children with exposure of less than 6 months. ${ }^{1}$

Giardia lamblia infection is more common in the 13 to 30 month-old children. ${ }^{1}$ Others said that children under five years of age are more frequently symptomatic than older children. ${ }^{4}$ Symptoms frequently reported in acute infections are loose, frequent, foul-smelling stools, malaise, fatigue, abdomi- 
nal cramps, distention, flatulence, anorexia, and nausea. In some individuals, weight loss may become significant. $4,6,8,11,14$ Giardia lamblia infection was significantly more common in toddlers than in infants. These results suggest that the differences in behavioral characteristics between infants and toddlers may result in different types of exposure to infectious agents. In toddlers, direct child-to-child transmission or contact with a contaminated environment may be more important than indirect transmission via the hands of staff. ${ }^{2}$

As a conclusion, the prevalence of Giardia lamblia among children attending daycare centers at Rancabali tea plantation, Bandung district was similar with other developing countries. More than half of patients had symptomatic disease. Thus, hygiene and sanitation in daycare centers need to be improved.

\section{References}

1. Pickering LK, Woodward WE, Du Pont HL, Sullivan P. Occurrence of Giardia lamblia in children in daycare centers. J Pediatr 1984;104:522-6.

2. Bartlett AV, Moore M, Gary GW, Starko KM, Erben JJ, Meredith BA. Diarrheal illness among infants and todlers in daycare centers. I. Epidemiology and pathogens. J Pediatr 1985;107:495-502.

3. Horowicz MI, Korman SH, Shapiro M, Har-Even U, Tamir I, Strauss N, et al. Asymptomatic giardiasis in children. Pediatr Infect Dis J 1989;8:773-9.
4. Turner JA. Giardiasis and infections with Dientamoeba fragilis. Pediatr Clin North Am 1985;32:865-75.

5. Rauch AM, Van Rory, Bartlett AV, Pickering LK. Longitudinal study of Giardia lamblia infection in a daycare center population. Pediatr Infect Dis J 1990;9:186-9.

6. Ortega YR, Adam RD. Giardia: overview and update. Clin Infect Dis 1997;25:545-9.

7. Farthing MJG, Cevalos AM, Kelly P. Intestinal protozoa. In: Cook GC, editor. Manson's tropical diseases; 20thed. Philadelphia: WB Saunders Co; 1996. p. 1271-81.

8. Hill DR. Giardiasis: issue in diagnosis and management. Infect Dis Clin North Am 1993;7:503-19.

9. Fraser D, Bilenko N, Dechelbaum RJ, Dagan R, El-On J, Naggan L. Giardia lamblia carriage in Israeli Bedouin infants: risk factors and consequences. Clin Infect Dis 2000;30:419-24.

10. Pickering LK. Giardiasis and balantidiasis. In: Nelson WE, Behrman RM, Kliegman RM, Jenson HB, editors. Nelson textbook of pediatrics; $16^{\text {th }}$ ed. Philadelphia: WB Saunders Co; 2000. p. 1036-8.

11. Pickering LK, Engelkirk PG. Giardia lamblia. Pediatr Clin North Am 1988;35:565-77.

12. Wright SG. Giardiasis. In: Strickland GT, editor. Hunter's tropical medicine; $7^{\text {th }}$ ed. Philadelphia: WB Saunders Co; 1991. p. 565-9.

13. Boyd RF, Hoerl BG. The protozoa. In: Boyd RF, Hoerl BG, editors. Basic medical microbiology; $4^{\text {th }}$ ed. London: Little, Brown and Co; 1991. p. 805-14.

14. Keating JP. Giardiasis. In: Feigin RD, Cherry JD, editors. Textbook of pediatric infectious diseases; $3^{\text {rd }}$ ed. Philadelphia: WB Saunders Co; 1992. p. 2032-5. 